\title{
Antioxidant Effect of some Plant Extracts as Compared with BHA/BHT on Lipid Oxidation and some Quality Properties of Fresh Beef Burgers Stored at $4^{\circ} \mathrm{C}$
}

\author{
Mokhtar, S. M. and Kh. M. Youssef \\ Food Technology Department, Faculty of Agriculture, Suez Canal University, Ismailia 41522, Egypt
}

Received: $25 / 11 / 2014$

\begin{abstract}
The properties of plants with food preservation potential are well known since the antiquity. In recent years, the use of herbs and spices to improve the sensory characteristics and to extend the shelf-life of foods has been growing. Antioxidant effect of adding rosemary extract (RE), sage extract (SE), oregano extract (OE), ginger extract (GE), clove extract (CE), tea catechins (TC) compared to BHA/BHT, on lipid oxidation and beef burger quality were investigated. The proximate composition, TBARS values, antioxidant activity (AOA\%), colour parameters (Hunter $L^{*}, a^{*}, b^{*}$ values, redness index and total colour difference), and sensory attributes of the beef burgers contained RE, SE, OE, GE, CE, TC and BHR/BHT during refrigerated storage at $4 \pm 1{ }^{\circ} \mathrm{C}$ for 15 days were determined and calculated. Significant reduction in TBARS values and colour changes for all treated beef burgers was observed during storage compared to control. TBARS values were significantly low in TC, followed by RE, CE, BHA/BHT, OE, SE and GE beef burgers. Antioxidant activity of the tested beef burgers was in the order TC $>\mathrm{RE}>\mathrm{CE}>\mathrm{BHA} / \mathrm{BHT}>\mathrm{OE}>\mathrm{SE}>\mathrm{GE}$, sensory scores were in agreement with these results. So, TC, RE and $\mathrm{CE}$ prevent lipid oxidation in beef burgers, and could be used in place of synthetic antioxidants, which have proved for their negative health implications.
\end{abstract}

Keywords: Plant extracts, BHA/BHT, Lipid oxidation, Chilling storage, Antioxidant activity, Beef burger quality.

\section{INTRODUCTION}

Recently, antioxidant-supplemented foods have gained a great deal of interest from consumers because of the growing awareness of cancer prevention and the risk of free radicals in the diet. The aim of food producers, food processors and food scientists has been to increase nutritional value of food products supplemented with antioxidants while simultaneously improving formulas for consumer acceptability. Meat products, due to fat content are highly susceptible to lipid oxidation. Moisture, prooxidant pigments, storage, handling and display conditions contribute to lipid oxidation of meat products. Grinding of meat disrupts the integrity of muscle membranes and exposes lipid membranes to metal ions and facilitates the interaction of pro-oxidants with unsaturated fatty acids resulting in generation of free radicals and propagation of oxidative reaction (Ibrahim et al., 2010 and Yogesh and Ali, 2014).

Lipid oxidation is a major cause of deterioration in the quality of meat products (Asghar et al., 1988) because it has detrimental effects on the colour, flavour and texture of meat which render these foods less acceptable. Lipid oxidation can have negative effects on the quality of meat and meat products causing changes in sensory attributes (colour, texture and flavour) and nutritional quality (Fenaille et al., 2003; Goodridge et al., 2003; Ripoll et al., 2011; Trefan et al., 2011 and Vaithiyanathan et al., 2011). One method to reduce lipid oxidation is the application of antioxidants.

The oxidation of lipids in foodstuffs results in the development of off-flavours, rendering the product unacceptable for human consumption and limiting the shelf-life of products. The structure of foods is changed during processing, and as a result, lipids may become more exposed to oxygen. In addition, naturally occurring antioxidant systems are impaired during processing, making processed food more susceptible to oxidation. Oxidative reactions can decrease the nutritional quality of food, and certain oxidation products are potentially toxic of meat and meat products which are reflected in economic losses and health disorders (Insani et al., 2008). The physical and chemical changes alter meat quality during the conversion of muscle to meat, including discolouration, development of off flavours, odours and texture changes (McMillin, 1996). However, the oxidation of myoglobin and lipids during refrigerated storage reduces the colour and flavour acceptability of fresh meat (Trout, 2003).

Usually, antioxidants such as butylated hydroxytoluene (BHT) and butylaled hydroxyanisole (BHA), both powerful synthetic antioxidants, are used to reduce the rate of oxidation processes. However, these antioxidants suffer from the drawback that they are volatile and readily decompose at high temperatures (Martinez-Tome et al. 2001). Additionally, they are believed to possess carcinogenic activity. With increased consumer concerns about the amount of chemicals in their foods, processors are looking for more natural ways to protect their products. In the last few years, there has been an increasing interest in the use of natural additives in preference to synthetic substances for the stabilization of fat-containing foodstuffs. These observations have led to a demand for antioxidants derived from naturally occurring sources (Lindberg et al., 1995). Many herbs and spices, usually added to season dishes, are an excellent source of phenolic compounds, which have been reported to show good antioxidant activity (Zheng and Wang, 2001). Antioxidants can prevent lipid peroxidation using the following mechanisms: preventing chain inhibition by scavenging initiating radicals, breaking chain reaction, decomposing peroxides, decreasing localized oxygen concentrations and binding chain initiating catalysts, such as metal ions (Dorman et al., 2003).

Rosemary (Rosmarinus officinalis L.) and sage (Salvia officinalis L.) are popular Labiatae herbs with known potent antioxidant activity (Estévez et al., 2006). 
Carnosic acid, carnosol, rosmarinic acid, rosmanol, and phenolic acids are the major phenolic constituents of these plants (Karakaya et al., 2011). Oregano (Origanum vulgare L.) also is Labiatae family and had a potent antioxidant activity. Derivatives of phenolic acids, flavonoids, tocopherols are the major constituents (Karakaya et al., 2011). Clove (Eugenia caryophyllus) is a member of Caryophyllaceae family was the strongest antioxidant in retarding lipid oxidation (Shan et al., 2009). The superior antioxidant activity of clove may arise from its high content of eugenol (3.0\%) and gallic acid (1.3\%) (Shahidi and Pegg, 1998). Ginger (Zingiber officinale) is a member of Zingiberaceae family and it is known to has antioxidant activity for long time. The antioxidant activity of ginger was attributable to gingerol-related compounds and diarylheptanoids (Karakaya et al., 2011 and Ibrahim et al., 2011) Tea catechins, the predominant group of polyphenols present in green tea leaves (Camellia sinensis) composed of four compounds epicatechin, epicatechin gallate, epigallocatechin and epigallocatechin gallate (Zhong et al., 2009). The effectiveness of rosemary, sage, clove, oregano, ginger and tea catechins as antioxidants has been demonstrated in a large variety of foodstuffs including beef and pork (Fasseas et al., 2008; Mitsumoto et al., 2005; Nissen et al., 2004 and Shahidi et al., 1995), buffalo meat (Naveena et al., 2006), pork sausages (Sebranek et al., 2005) and beef, duck, ostrich, pork and chicken (McCarthy et al., 2001; Mitsumoto et al., 2005 and Tang et al., 2001).

The objective of this study was to determine whether natural antioxidants namely, [(rosemary extract (RE), sage extract (SE), oregano extract $(\mathrm{OE})$, ginger extract (GE), clove extract (CE) and Tea catechins (TC) are sufficiently potent to replace the synthetic antioxidants namely BHA/BHT currently used in beef burgers.

\section{MATERIALS AND METHODS}

\section{Materials}

Fresh beef loin (Longissimus dorsi) muscles were obtained from local retail meat processing plants (Ismailia, Egypt). Fresh meat samples were obtained separately for each of the replications. 2-Thiobarbituric acid (TBA), butylated hydroxyanisole (BHA) and butylated hydroxytoluene (BHT) were obtained from Sigma-Aldrich Chemical Co. (St. Louis, MO, USA). All other chemicals used were of analytical grade or the highest grade available and were obtained either from Sigma-Aldrich, Merck (Darmstadt, Germany) or LabScan Ltd., Dublin, Irland.

\section{Plant Extracts Powder}

Rosemary extract (Guardian ${ }^{\mathrm{TM}}$ ) was purchased from Danisco, Denmark. Clove and ginger extracts, and tea catechins 98\% were obtained from Sigma-Aldrich Chemical Co. (St. Louis, MO, USA). Sage and oregano extracts were obtained from Kingherbs Ltd., Changsha, China.

\section{Preparation of Beef Burgers}

Fresh beef loin muscles were chopped into small pieces after removal of visible fat and connective tissues. Chopped meat samples were minced using a meat mincer (Bizerba, Wilhelm Kraut GmbH \& Co KG, Germany) through a plate with 4- mm holes. Portions of uniform weight of the minced muscles were mixed in a Classic Chef-KM353 Kenwood meat mixer ( Kenwood Ltd., Havant, UK) for $5 \mathrm{~min}$ with salt $(2 \% \mathrm{w} / \mathrm{w})$ and adding the tested extracts to minced meat and assigned as follows: (1) control (without adding any extracts) ; (2) 200 ppm RE; (3) 200 ppm SE; (4) 200 ppm OE; (5) 200 ppm GE; (6) 200 ppm CE; (7) 200 ppm TC; and (8) $200 \mathrm{ppm}$ BHA/BHT in a $1: 1$ ratio. After mixing, beef burgers of $50 \pm 1 \mathrm{~g}$ were formed using a beef burger former (Italmans, Italy). The beef burgers were placed on Styrofoam trays, wrapped with polyethylene film and kept in refrigerator at $4 \pm 1{ }^{\circ} \mathrm{C}$ for 15 days. All experiments were repeated thrice in order to remove effects deriving from the initial quality of raw material.

TBARS values were determined in the beef burger samples for $0,1,3,6,9,12$ and 15 days of storage period and antioxidant activity (AOA \%) was calculated. Also, $\mathrm{pH}$ and instrumental color attributes were analyzed in beef burger samples at $0,1,3,6,9,12$ and 15 days of storage period. Whereas, sensory attributes were performed on cooked samples after 0,3 , $6,9,12$ and 15 days of cold storage.

\section{Proximate Analysis}

Moisture (hot air oven), protein (Kjeldahl, $\mathrm{N} \times$ 6.25), fat (ether extractable), and ash were determined only in the initial meat mixture used for the preparation of the experimental beef burgers according to AOAC (2000).

\section{pH Determination}

A raw beef burger sample $10 \mathrm{~g}$ was homogenized in $90 \mathrm{ml}$ distilled water for $1 \mathrm{~min}$ in a blender. The $\mathrm{pH}$ values were measured using a Jenway $\mathrm{pH}$ meter (Jenway 3010; Jenway Ltd., Essex, UK).

\section{Thiobarbituric Acid Reactive Substances (TBARS) Measurement}

Lipid oxidation of the beef burger samples from each treatment and storage day was determined using the distillation 2-thiobarbituric acid (TBA) procedure of Tarladgis et al. (1960) with modified by Shahidi et al. (1987). Distillates of $10 \mathrm{~g}$ samples were reacted with TBA reagent $(0.02 \mathrm{M}$ aqueous solution of 2thiobarbituric acid) and the absorbance of the resultant pink-coloured chromogen was measured at $532 \mathrm{~nm}$ using a spectrophotometer (6505 UV/Vis, Jenway Ltd., Felsted, Dunmow, UK). Values of absorbance at 532 nm were multiplied by 8.1 and expressed as TBARS numbers in $\mathrm{mg}$ malonaldehyde equivalents $/ \mathrm{kg}$ of meat sample.

\section{Instrumental Color Measurement}

The measurement of (CIE) color values $L^{*}$ (lightness), $a^{*}$ (redness) and $b^{*}$ (yellowness) was conducted on the surface of the beef burger samples from day zero to day 15 with a using a color reader CR10 (Konica Minolta, Inc., Osaka, Japan). The redness index $\left(a * / b^{*}\right)$ was determined as described by Chen et al. (1997). A numerical total color difference $(\Delta \mathrm{E})$ between beef burgers on 0 and 15 days of storage was 
calculated according to Vega-Gálvez et al. (2012) as follows:

$\Delta \mathrm{E}=\left[\left(L^{*} 15-L^{*} 0\right)^{2}+\left(a^{*} 15-a * 0\right)^{2}+\left(b^{*} 15-b^{*} 0\right)^{2}\right]^{1 / 2}$

\section{Sensory Evaluation}

Samples of beef burgers were evaluated according to the method described by García et al. (2009), ten experienced panelists were chosen from the staff members of the Department of Food Technology at Faculty of Agriculture, Suez Canal University, Ismailia, Egypt. Panelists were selected according to their habits, their familiarity with the burgers to be analyzed, their sensitivity and the ability to reproduce the evaluation made. Moreover, they received a preparatory session prior to testing so that each panelist could thoroughly discuss and clarify each attribute to be evaluated. Eight beef burgers were cooked on a preheated electric grill (WA-BBQ 01, White Whale, China) at approximately $180{ }^{\circ} \mathrm{C}$ for $2 \mathrm{~min}$, then turned over and cooked for another $2 \mathrm{~min}$. The temperature of the centre of burgers reached approximately $80{ }^{\circ} \mathrm{C}$. A beef burger of each sample was served to the panelists. Beef burgers were pre warmed before serving and water was served for rinsing the mouth between samples (Kanatt et al., 2010).

A hedonic test was carried out using non-structured 9 point scales $(0=$ dislike extremely and $9=$ like extremely) in which the panelists evaluated different attributes: colour, texture, odour, taste and overall acceptability.

\section{Statistical Analysis}

The conventional statistical methods were used to calculate means and standard deviations, All the measurements were replicated three times and the data are presented as mean $\pm \mathrm{SD}$. The effects of natural antioxidant extracts addition and storage period were analyzed and the obtained data were subjected to analysis of variance (ANOVA) accompanied with Duncan test using SPSS software (version 16.0 for Windows, SPSS Inc., Chicago) were conducted to identify the significance $(p<0.05)$ between means of treatments.

\section{RESULTS AND DISCUSSION}

\section{Chemical Composition of Meat Mixture}

Mean values of chemical composition of the meat mixture used for the preparation of the experimental beef burgers are presented in Table 1. The moisture of minced meat averaged $66.7 \%$, total crude protein $18.6 \%$, crude fat $13.2 \%$ and ash $096 \%$.

\section{pH Changes}

The effect of natural and synthetic antioxidants on $\mathrm{pH}$ values of beef burgers stored at $4 \pm 1{ }^{\circ} \mathrm{C}$ is presented in Table 2. At zero time the $\mathrm{pH}$ of the control and all tested samples had the values ranged (5.79-5.83). The $\mathrm{pH}$ values of all treatments were similar $(\mathrm{p}>0.05)$; therefore, it was not affected by the antioxidants addition. These results are in agreement with the results obtained by Mohamed and Mansour (2012) who reported that the addition of natural herbal extracts to beef patties did not significantly change the $\mathrm{pH}$ values of all formulas after preparation and during storage. The
$\mathrm{pH}$ values of all beef burger samples decreased slowly during the first 3 days of storage, whereas after day 3 there was a gradual increase. The increase in $\mathrm{pH}$ may be due the accumulation of metabolites by bacterial action in meat and deamination of proteins (Jay, 1996). Bacteria, upon exhaustion of stored glucose, utilize amino acids released during protein breakdown and as a product of amino acid degradation, ammonia accumulates and $\mathrm{pH}$ rises (Gill, 1983). During storage time (3-15 days) it was noticed that the $\mathrm{pH}$ value of the control was higher (6.01) than the other tested samples. At the $15^{\text {th }}$ day beef burger containing RE and SE extracts had the highest $\mathrm{pH}$ value (5.96) and the beef burger containing BHA/BHT had the lowest value (5.91). Similar findings in pork patties containing natural food and plant extracts, and BHA/BHT antioxidants during refrigerated storage have been reported by (McCarthy et al., 2001).

Table (1): Proximate analysis of the meat mixture used for the preparation of beef burgers

\begin{tabular}{lc}
\hline Component (\%) & Mean \pm SD \\
\hline Moisture & $66.7 \pm 0.53$ \\
Protein & $18.6 \pm 0.36$ \\
Fat & $13.2 \pm 0.44$ \\
Ash & $0.96 \pm 0.07$ \\
\hline
\end{tabular}

Data represent averages of three independent repeats \pm standard deviation

TBARS Values and Antioxidant Activity (AOA \%)

Effect of plant extracts: RE, SE, OE, GE, CE, TC as well as BHA/BHT on thiobarbituric acid reactive substances (TBARS) values in fresh beef burgers stored at $4 \pm 1{ }^{\circ} \mathrm{C}$ for 15 day are shown in Table 3. All antioxidant treatments significantly $(\mathrm{P}<0.05)$ reduced the TBARS values throughout storage compared to the control sample. The effectiveness of the added antioxidants inhibiting lipid oxidation throughout storage time could be listed in the following order of decreasing TBARS values: $\mathrm{TC}>\mathrm{RE}>\mathrm{CE}>\mathrm{OE}>$ $\mathrm{BHA} / \mathrm{BHT}>\mathrm{SE}>\mathrm{GE}$. Results also showed that the TC extract was the most effective antioxidant and GE had the lowest effect. This can indicate that natural extracts used as antioxidants was effective against TBARS formation at different way when incorporated into beef burgers. Chen et al. (1999); Formanek et al. (2001) and McCarthy et al. (2001) reported that dried herbs and their essential oils were successfully used to reduced lipid oxidation in meat products. The large amount of phenolic compounds may cause its strong antioxidant ability (Li et al., 2006). Polyphenolic extracts are excellent electron and proton donors, and their intermediate radicals are quite stable due to electron delocalization phenomena and owning to the lack of positions attackable by $\mathrm{O}_{2}$ (Djenane et al., 2005). In the present study, since the natural extracts used in preparing beef burgers contain bioactive substances e.g. phenolic compounds which cause an inhibition of the chain reactions during lipid oxidiation. Again, these phenolic compounds might be involved in the inhibition of lipid oxidation, by inhibiting free radical formation, 
by preventing propagation of free radical chain reactions through the chelation of transition metal ions, particularly those of iron and copper (Brown et al., 1998).

The total antioxidant activity or capacity has been generally recognized as a tool to test the antioxidant potential of a pure compound or a food extract (Aruoma, 1996). Antioxidant activity of a food could be a useful index to predict oxidative stability (Sacchetti et al., 2008). Data on the antioxidant activity of beef burgers as affected by addition natural extracts as antioxidants stored at $4+1{ }^{\circ} \mathrm{C}$ for 15 days are depicted in Table 3. Within the tested samples, a significant difference between the $\mathrm{AOA} \%$ as a result of adding the natural extracts during storage for 15 days was observed. The order of antioxidant activity was TC $>$ $\mathrm{RE}>\mathrm{CE}>\mathrm{BHA} / \mathrm{BHT}>\mathrm{OE}>\mathrm{SE}>\mathrm{GE}$. It was also, noticed that $\mathrm{TC}$ exhibited a higher $\mathrm{AOA} \%$ than other tested samples at storage periods. The data indicated that the marked antioxidant activity of TC, RE as well as CE seemed to be the result of their radical scavenging activity. The phenolics may act in a similar fashion as reductones by donating electrons and reacting with free radicals to convert them to more stable products and terminate free radical chain reactions (Negi and Jayaprakasha, 2003). This result was consistent with studies in precooked roast beef (Murphy et al., 1998). Mitsumoto et al. (2005) reported that TC treatments greatly suppressed $(\mathrm{P}<0.01)$ lipid oxidation in meat patties compared to controls and vitamin $\mathrm{C}$ treatments. Also, Trindade et al. (2007) concluded that rosemary extracts contain phenolic primary antioxidants which react with lipid or hydroxyl radicals and convert them into stable products. Also, Fang and Wada (1993) demonstrated that the rosemary extracts may chelate metal ions, such as $\mathrm{Fe}^{2+}$ resulting in a reduce rate of formation of activated oxygen.

\section{Colour Evaluation}

Colour is one of the most important sensory qualities as it helps us to accept or reject particular food items. Colour is important in consumer perception of food and it is often associated with a specific flavour and intensity of flavour. The effect of natural and synthetic antioxidants on the colour parameters of beef burgers stored at $4 \pm 1{ }^{\circ} \mathrm{C}$ is presented in Table 4 . In general, as the storage days number increased, $L^{*}, a^{*}$ and $b^{*}$ values decreased, the amount of discolouration increased, and the colour was darker. For $L^{*}$ value, fresh beef burgers with TC had the highest value $(\mathrm{P}<0.05)$ compared to other treatments. Also, samples with TC and with RE had significantly $(\mathrm{P}<0.05)$ higher $a^{*}$ values than those of the control and samples with any other antioxidants, throughout the whole period of storage. The CE, BHA/BHT, OE and SE also gave significantly higher $a^{*}$ values $(\mathrm{P}<0.05)$ than those of the control over a 15-days storage period. At the end of the storage period, the control samples and those with GE had very low $a^{*}$ values below 7. Therefore, according to our results, addition of TC and RE maintained the red colour of beef burgers better than control and other treatment samples. The decrease of $a^{*}$ value during storage is probably due to oxymyoglobin oxidation to metmyoglobin. The iron in oxymyoglobin is in the reduced state $\left(\mathrm{Fe}^{2+}\right)$, but the iron in metmyoglobin is in the oxidised state $\left(\mathrm{Fe}^{3+}\right)$. The effectiveness of an antioxidant, in terms of colour stability, is determined by its ability to keep iron in the reduced state which results in a desirable colour. Once iron has been oxidised, it cannot be converted back to its reduced state, thus the shift from oxymyoglobin to metmyoglobin is permanent (Jenschke, 2004). The observed effect of TC and RE was in agreement with the results reported by Maher et al. (2002), who showed that addition of TC and rosemary to minced raw beef greatly improved colour compared to controls. Also, a reduction in metmyoglobin formation was noticed and intense red colour obtained in fresh beef steaks whose surface was sprayed with rosemary during refrigeration (Djenane et al., 2005).

At day 0 , the redness index $\left(a * / b^{*}\right.$ ratio $)$ of tested samples was higher. The redness index of beef burger samples decreased when the storage time increased. This ratio was used as an index of apparent change in redness (Chen et al., 1997), and used to evaluate the discolouration in tuna meat during storage (Lee et al., 2003). Boulianne and King (1998) showed a strong positive correlation between total pigment concentration and $a^{*}$ values. The decrease in the redness index was associated with the darkening of meats, resulting from the formation of metmyoglobin. Faustman et al. (1992) reported that the saturation of red color in meat was directly related to myoglobin concentration. Fleming et al. (1991) reported that dark colouration in meat was also associated with the total pigment concentration. Thus, the changes in the redness index can be used as the index of pigment changes of beef burgers.

The overall color change $(\Delta \mathrm{E})$ demonstrated that the addition of TC protect against discolouration of the beef burgers $(p<0.05)$. The result of our study showed (Figure 1) a good correlation $\left(\mathrm{R}^{2}=0.7442\right)$ between $\mathrm{AOA} \%$ and $\triangle \mathrm{E}$ of beef burger samples. Many undesired chemical reactions can take place among which lipid oxidation is the most unfavourable and can negatively affect the colour of the meat product. Lipid oxidation reactions usually also interacts with haem pigments and so can turn their red colour brown. Kong et al. (2010) observed that clove, rosemary and cassia bark extracts to be highly effective antioxidants in cooked pork patties as they inhibited lipid oxidation and stabilized red colour (myoglobin) during refrigerated storage. Oxidation of lipids and muscle pigments is one of the main parameters of meat quality deterioration. Lipid oxidation causes development of off-odours and off flavours; muscle pigment oxidation negatively affects colour, appearance and acceptability (Kolakowska, 2003).

\section{Sensory Evaluation}

The effect of natural and synthetic antioxidants on the sensorial criteria of beef burgers stored at $4 \pm 1{ }^{\circ} \mathrm{C}$ is presented in Table 5. Alterations in food quality as a result of lipid oxidation range from colour variations to changes in appearance, odour/aroma, texture and taste. Sensory evaluations are the most significant methods for predicting oxidative stability, product shelf life and consumer acceptability (Rajalakshmi and Narasimhan, 
1996). Colour is an important factor for consumer acceptance of meat and its products. The shelf life and quality of meat products are strongly influenced by the initial meat quality, additives, packaging parameters, and storage conditions. In general, all beef burger samples treated with natural and synthetic antioxidants had significantly $(\mathrm{P}<0.05)$ higher colour, odour, taste and overall acceptability scores than the control. Results clearly demonstrated that beef burgers treated with TC and RE were given higher scores than any other beef burgers throughout the whole storage period, for colour, taste, odour and overall acceptability, followed by CE, BHA/BHT, SE, OE and GE, which also differed significantly from the control $(\mathrm{P}<0.05)$. This intensity order of the protective ability on beef burgers quality of the examined antioxidants, as measured by sensory evaluation, consistently agreed with their effectiveness in preventing both lipid and myoglobin oxidation. Also, the reduction of the rate of lipid oxidation by antioxidants during storage probably prevents the formation of secondary oxidation products and consequently decreases the rate of odour and taste deterioration. The results in Figure (2), showed a high correlation $\left(\mathrm{R}^{2}=0.9026\right)$ between TBARS values $(\mathrm{mg}$ malonaldehyde/kg meat sample) and odour sensory scores. As regards to texture, the texture scores of all treatments and control were similar $(\mathrm{p}>0.05)$ when different antioxidants were added; therefore, the texture of beef burgers was not affected by addition of different antioxidants. These data are in agreement with Mohamed and Mansour, (2012) who reported that beef patties prepared with addition of rosemary and marjoram essential oils had significantly $(\mathrm{P}<0.05)$

Table (2): Effect of natural and synthetic antioxidants on $\mathrm{pH}$ values of beef burgers during storage at $4 \pm 1^{\circ} \mathrm{C}$

\begin{tabular}{llllllll}
\hline \multirow{2}{*}{ Treatment } & \multicolumn{7}{c}{ Storage time (days) } \\
\cline { 2 - 8 } & $\mathbf{0}$ & $\mathbf{1}$ & $\mathbf{3}$ & $\mathbf{6}$ & $\mathbf{9}$ & $\mathbf{1 2}$ & $\mathbf{1 5}$ \\
\hline CON & $5.83 \pm 0.035 \mathrm{a}$ & $5.81 \pm 0.025 \mathrm{a}$ & $5.78 \pm 0.046 \mathrm{a}$ & $5.80 \pm 0.049 \mathrm{a}$ & $5.83 \pm 0.068 \mathrm{a}$ & $5.89 \pm 0.049 \mathrm{a}$ & $6.01 \pm 0.056 \mathrm{a}$ \\
RE & $5.79 \pm 0.030 \mathrm{a}$ & $5.78 \pm 0.015 \mathrm{a}$ & $5.75 \pm 0.032 \mathrm{a}$ & $5.76 \pm 0.015 \mathrm{a}$ & $5.82 \pm 0.059 \mathrm{a}$ & $5.85 \pm 0.040 \mathrm{a}$ & $5.96 \pm 0.042 \mathrm{a}$ \\
SE & $5.83 \pm 0.055 \mathrm{a}$ & $5.82 \pm 0.052 \mathrm{a}$ & $5.78 \pm 0.055 \mathrm{a}$ & $5.81 \pm 0.059 \mathrm{a}$ & $5.84 \pm 0.076 \mathrm{a}$ & $5.90 \pm 0.059 \mathrm{a}$ & $5.96 \pm 0.040 \mathrm{a}$ \\
OE & $5.82 \pm 0.050 \mathrm{a}$ & $5.79 \pm 0.031 \mathrm{a}$ & $5.76 \pm 0.038 \mathrm{a}$ & $5.79 \pm 0.036 \mathrm{a}$ & $5.83 \pm 0.075 \mathrm{a}$ & $5.88 \pm 0.051 \mathrm{a}$ & $5.93 \pm 0.053 \mathrm{a}$ \\
GE & $5.79 \pm 0.029 \mathrm{a}$ & $5.75 \pm 0.040 \mathrm{a}$ & $5.73 \pm 0.025 \mathrm{a}$ & $5.76 \pm 0.025 \mathrm{a}$ & $5.79 \pm 0.061 \mathrm{a}$ & $5.83 \pm 0.046 \mathrm{a}$ & $5.90 \pm 0.070 \mathrm{a}$ \\
CE & $5.82 \pm 0.017 \mathrm{a}$ & $5.78 \pm 0.025 \mathrm{a}$ & $5.73 \pm 0.020 \mathrm{a}$ & $5.75 \pm 0.025 \mathrm{a}$ & $5.77 \pm 0.035 \mathrm{a}$ & $5.82 \pm 0.032 \mathrm{a}$ & $5.92 \pm 0.049 \mathrm{a}$ \\
TC & $5.81 \pm 0.025 \mathrm{a}$ & $5.76 \pm 0.032 \mathrm{a}$ & $5.74 \pm 0.025 \mathrm{a}$ & $5.77 \pm 0.046 \mathrm{a}$ & $5.82 \pm 0.061 \mathrm{a}$ & $5.86 \pm 0.046 \mathrm{a}$ & $5.92 \pm 0.053 \mathrm{a}$ \\
BHA/BHT & $5.80 \pm 0.036 \mathrm{a}$ & $5.76 \pm 0.042 \mathrm{a}$ & $5.72 \pm 0.023 \mathrm{a}$ & $5.75 \pm 0.036 \mathrm{a}$ & $5.81 \pm 0.049 \mathrm{a}$ & $5.85 \pm 0.040 \mathrm{a}$ & $5.91 \pm 0.067 \mathrm{a}$ \\
\hline
\end{tabular}

CON: control (without antioxidant); RE: $0.2 \mathrm{~g}$ rosemary extract $/ \mathrm{kg}$ meat; SE: $0.2 \mathrm{~g}$ sage extract $/ \mathrm{kg}$ meat; OE: $0.2 \mathrm{~g}$ oregano extract $/ \mathrm{kg}$ meat; GE: $0.2 \mathrm{~g}$ ginger extract $/ \mathrm{kg}$ meat; CE: $0.2 \mathrm{~g}$ clove extract $/ \mathrm{kg}$ meat; TC: $0.2 \mathrm{~g}$ tea catechins $/ \mathrm{kg}$ meat; BHA/BHT: $0.2 \mathrm{~g}$ BHA/BHT (1:1)/kg meat.

Means in the same column for the same storage day with a different letter $(\mathrm{a}-\mathrm{g})$ differ significantly $(\mathrm{p}<0.05)$

Table (3): Effect of natural and synthetic antioxidants on TBARS values and AOA\% of beef burgers during storage at $4 \pm 1^{\circ} \mathrm{C}$

\begin{tabular}{|c|c|c|c|c|c|c|c|}
\hline \multirow{2}{*}{ Treatment } & \multicolumn{7}{|c|}{ Storage time (days) } \\
\hline & $\mathbf{0}$ & 1 & 3 & 6 & 9 & 12 & 15 \\
\hline \multicolumn{8}{|c|}{ TBARS values } \\
\hline CON & $0.21 \pm 0.025 \mathrm{a}$ & $0.32 \pm 0.035 \mathrm{a}$ & $0.55 \pm 0.036 \mathrm{a}$ & $0.78 \pm 0.035 \mathrm{a}$ & $0.99 \pm 0.027 \mathrm{a}$ & $1.18 \pm 0.042 \mathrm{a}$ & $1.22 \pm 0.040 \mathrm{a}$ \\
\hline $\mathbf{R E}$ & $0.18 \pm 0.017 \mathrm{ab}$ & $0.18 \pm 0.046 \mathrm{c}$ & $0.28 \pm 0.023 \mathrm{~d}$ & $0.31 \pm 0.040 \mathrm{~d}$ & $0.38 \pm 0.015 \mathrm{e}$ & $0.44 \pm 0.025 \mathrm{c}$ & $0.49 \pm 0.023 \mathrm{de}$ \\
\hline SE & $0.17 \pm 0.025 b$ & $0.19 \pm 0.025 \mathrm{c}$ & $0.30 \pm 0.055 \mathrm{~cd}$ & $0.36 \pm 0.035 \mathrm{~cd}$ & $0.43 \pm 0.015 \mathrm{cde}$ & $0.51 \pm 0.030 \mathrm{c}$ & $0.59 \pm 0.032 \mathrm{c}$ \\
\hline $\mathbf{O E}$ & $0.18 \pm 0.015 \mathrm{ab}$ & $0.20 \pm 0.025 \mathrm{bc}$ & $0.29 \pm 0.036 \mathrm{~cd}$ & $0.36 \pm 0.032 \mathrm{~cd}$ & $0.46 \pm 0.035 \mathrm{c}$ & $0.50 \pm 0.042 \mathrm{c}$ & $0.53 \pm 0.021 \mathrm{~d}$ \\
\hline GE & $0.20 \pm 0.027 \mathrm{ab}$ & $0.24 \pm 0.025 b$ & $0.38 \pm 0.052 b$ & $0.52 \pm 0.025 b$ & $0.68 \pm 0.045 b$ & $0.89 \pm 0.040 \mathrm{~b}$ & $0.96 \pm 0.032 b$ \\
\hline $\mathbf{C E}$ & $0.19 \pm 0.032 \mathrm{ab}$ & $0.20 \pm 0.015 b c$ & $0.28 \pm 0.027 \mathrm{~d}$ & $0.35 \pm 0.023 \mathrm{~cd}$ & $0.39 \pm 0.010 \mathrm{de}$ & $0.48 \pm 0.055 \mathrm{c}$ & $0.50 \pm 0.017 \mathrm{de}$ \\
\hline $\mathbf{T C}$ & $0.18 \pm 0.015 \mathrm{ab}$ & $0.18 \pm 0.012 \mathrm{c}$ & $0.27 \pm 0.021 \mathrm{~d}$ & $0.33 \pm 0.023 \mathrm{~cd}$ & $0.39 \pm 0.044 \mathrm{de}$ & $0.44 \pm 0.032 \mathrm{c}$ & $0.45 \pm 0.027 \mathrm{e}$ \\
\hline $\begin{array}{l}\text { ВНА/BНT } \\
\text { AOA } \%\end{array}$ & $0.21 \pm 0.021 \mathrm{a}$ & $0.20 \pm 0.027 \mathrm{bc}$ & $0.35 \pm 0.035 b c$ & $0.38 \pm 0.046 \mathrm{c}$ & $0.44 \pm 0.051 \mathrm{~cd}$ & $0.50 \pm 0.040 \mathrm{c}$ & $0.54 \pm 0.053 \mathrm{~cd}$ \\
\hline RE & $16.97 \pm 1.063 \mathrm{ab}$ & $43.39 \pm 1.894 \mathrm{a}$ & $48.38 \pm 1.708 \mathrm{a}$ & $59.76 \pm 1.544 \mathrm{a}$ & $61.96 \pm 0.848 \mathrm{a}$ & $62.55 \pm 0.856 \mathrm{a}$ & $59.57 \pm 0.986 b$ \\
\hline SE & $18.92 \pm 1.418 \mathrm{a}$ & $41.16 \pm 0.442 \mathrm{ab}$ & $45.11 \pm 3.219 \mathrm{a}$ & $54.15 \pm 1.410 \mathrm{bc}$ & $56.91 \pm 0.806 b c$ & $56.92 \pm 0.221 b$ & $51.38 \pm 0.540 \mathrm{~d}$ \\
\hline $\mathbf{O E}$ & $13.83 \pm 1.684 b$ & $35.83 \pm 1.010 \mathrm{c}$ & $47.41 \pm 1.132 \mathrm{a}$ & $53.27 \pm 0.760 \mathrm{bc}$ & $53.91 \pm 0.778 \mathrm{c}$ & $57.51 \pm 0.715 b$ & $56.29 \pm 0.524 c$ \\
\hline GE & $4.73 \pm 0.549 \mathrm{~d}$ & $23.10 \pm 1.010 \mathrm{~d}$ & $31.06 \pm 1.684 b$ & $32.62 \pm 0.639 \mathrm{~d}$ & $31.02 \pm 1.542 \mathrm{~d}$ & $25.09 \pm 0.888 \mathrm{c}$ & $21.04 \pm 0.961 \mathrm{e}$ \\
\hline $\mathbf{C E}$ & $9.46 \pm 0.709 c$ & $37.74 \pm 1.263 \mathrm{bc}$ & $49.12 \pm 1.745 \mathrm{a}$ & $54.52 \pm 0.684 b c$ & $60.60 \pm 0.347 \mathrm{ab}$ & $59.50 \pm 0.473 \mathrm{ab}$ & $59.01 \pm 0.715 b$ \\
\hline $\mathbf{T C}$ & $14.19 \pm 1.063 \mathrm{~b}$ & $44.35 \pm 0.631 \mathrm{a}$ & $50.33 \pm 0.566 a$ & $57.10 \pm 0.849 \mathrm{ab}$ & $60.66 \pm 0.454 \mathrm{ab}$ & $62.57 \pm 0.163 \mathrm{a}$ & $63.13 \pm 0.265 \mathrm{a}$ \\
\hline BHA/BHT & $0.00 \pm 0.00 \mathrm{e}$ & $36.88 \pm 1.010 \mathrm{c}$ & $35.84 \pm 0.173 b$ & $51.18 \pm 1.054 \mathrm{c}$ & $55.29 \pm 1.867 \mathrm{c}$ & $57.50 \pm 0.221 b$ & $55.80 \pm 0.177 \mathrm{c}$ \\
\hline
\end{tabular}

CON: control (without antioxidant); RE: $0.2 \mathrm{~g}$ rosemary extract $/ \mathrm{kg}$ meat; SE: $0.2 \mathrm{~g}$ sage extract $/ \mathrm{kg}$ meat; OE: $0.2 \mathrm{~g}$ oregano extract $/ \mathrm{kg}$ meat; GE: $0.2 \mathrm{~g}$ ginger extract $/ \mathrm{kg}$ meat; CE: $0.2 \mathrm{~g}$ clove extract $/ \mathrm{kg}$ meat; TC: $0.2 \mathrm{~g}$ tea catechins $/ \mathrm{kg}$ meat; BHA $/ \mathrm{BHT}: 0.2 \mathrm{~g}$ BHA/BHT (1:1)/kg meat.

Means in the same column for the same storage day with a different letter $(\mathrm{a}-\mathrm{g})$ differ significantly $(\mathrm{p}<0.05)$ 
Table (4): Effect of natural and synthetic antioxidants on Hunter colour values $\left(L^{*}, a^{*}\right.$ and $\left.\mathrm{b}^{*}\right)$, redness index $\left(a^{*} / b^{*}\right)$ and the numerical total colour difference $(\Delta \mathrm{E})$ between day 0 and day 15 of beef burgers during storage at $4 \pm 1^{\circ} \mathrm{C}$

\begin{tabular}{|c|c|c|c|c|c|c|}
\hline $\begin{array}{l}\text { Storage } \\
\text { time (days) }\end{array}$ & Treatment & $L^{*}$ & $a^{*}$ & $b^{*}$ & $a * / b *$ & $\Delta \mathbf{E}$ \\
\hline \multirow[t]{8}{*}{0} & $\mathrm{CON}$ & $45.87 \pm 0.072 \mathrm{e}$ & $12.58 \pm 0.093 c$ & $11.89 \pm 0.056 \mathrm{c}$ & $1.06 \pm 0.013 b$ & - \\
\hline & RE & $47.58 \pm 0.055 \mathrm{a}$ & $12.85 \pm 0.041 \mathrm{~b}$ & $12.22 \pm 0.098 \mathrm{a}$ & $1.05 \pm 0.011 \mathrm{~b}$ & - \\
\hline & SE & $45.98 \pm 0.067 \mathrm{e}$ & $12.30 \pm 0.128 \mathrm{~d}$ & $12.04 \pm 0.086 \mathrm{~b}$ & $1.02 \pm 0.010 \mathrm{~d}$ & - \\
\hline & OE & $46.89 \pm 0.087 \mathrm{c}$ & $12.32 \pm 0.084 \mathrm{~d}$ & $11.78 \pm 0.104 d$ & $1.05 \pm 0.016 \mathrm{bc}$ & - \\
\hline & GE & $46.72 \pm 0.066 \mathrm{~d}$ & $12.05 \pm 0.148 \mathrm{e}$ & $11.66 \pm 0.088 \mathrm{e}$ & $1.03 \pm 0.009 \mathrm{~cd}$ & - \\
\hline & $\mathbf{C E}$ & $47.64 \pm 0.118 \mathrm{a}$ & $12.60 \pm 0.037 \mathrm{c}$ & $11.89 \pm 0.093 \mathrm{c}$ & $1.06 \pm 0.011 \mathrm{~b}$ & - \\
\hline & TC & $47.22 \pm 0.158 b$ & $13.09 \pm 0.134 \mathrm{a}$ & $11.82 \pm 0.079 \mathrm{~cd}$ & $1.11 \pm 0.017 \mathrm{a}$ & - \\
\hline & ВНА/ВНТ & $46.78 \pm 0.067 \mathrm{~cd}$ & $12.62 \pm 0.074 \mathrm{c}$ & $12.29 \pm 0.037 \mathrm{a}$ & $1.03 \pm 0.004 \mathrm{~d}$ & - \\
\hline \multirow[t]{8}{*}{1} & CON & $45.58 \pm 0.164 \mathrm{~g}$ & $11.80 \pm 0.131 \mathrm{~d}$ & $11.41 \pm 0.070 \mathrm{ef}$ & $1.03 \pm 0.008 \mathrm{de}$ & - \\
\hline & $\mathbf{R E}$ & $47.98 \pm 0.059 \mathrm{a}$ & $12.90 \pm 0.106 \mathrm{a}$ & $12.08 \pm 0.086 \mathrm{a}$ & $1.07 \pm 0.001 \mathrm{~b}$ & - \\
\hline & SE & $46.13 \pm 0.052 f$ & $12.12 \pm 0.040 \mathrm{c}$ & $11.85 \pm 0.074 \mathrm{c}$ & $1.02 \pm 0.008 \mathrm{e}$ & - \\
\hline & OE & $46.70 \pm 0.082 \mathrm{e}$ & $12.02 \pm 0.074 \mathrm{c}$ & $11.44 \pm 0.091 \mathrm{e}$ & $1.05 \pm 0.012 \mathrm{c}$ & - \\
\hline & GE & $46.97 \pm 0.130 \mathrm{~d}$ & $11.09 \pm 0.113 \mathrm{e}$ & $11.32 \pm 0.125 f$ & $0.98 \pm 0.018 \mathrm{f}$ & - \\
\hline & $\mathbf{C E}$ & $47.55 \pm 0.076 \mathrm{c}$ & $12.42 \pm 0.069 b$ & $11.96 \pm 0.088 \mathrm{bc}$ & $1.04 \pm 0.010 \mathrm{~cd}$ & - \\
\hline & TC & $47.86 \pm 0.035 b$ & $13.66 \pm 0.070 \mathrm{a}$ & $11.59 \pm 0.102 \mathrm{~d}$ & $1.12 \pm 0.009 \mathrm{a}$ & - \\
\hline & BHA/BHT & $47.06 \pm 0.038 \mathrm{~d}$ & $12.40 \pm 0.063 \mathrm{~b}$ & $11.98 \pm 0.044 \mathrm{ab}$ & $1.04 \pm 0.007 \mathrm{de}$ & - \\
\hline \multirow[t]{8}{*}{3} & CON & $46.98 \pm 0.087 \mathrm{e}$ & $9.67 \pm 0.143 \mathrm{f}$ & $10.87 \pm 0.058 \mathrm{f}$ & $0.89 \pm 0.013 \mathrm{f}$ & - \\
\hline & RE & $48.07 \pm 0.052 b$ & $11.98 \pm 0.099 \mathrm{ab}$ & $11.59 \pm 0.096 \mathrm{a}$ & $1.03 \pm 0.014 b$ & - \\
\hline & SE & $47.02 \pm 0.093 \mathrm{e}$ & $11.29 \pm 0.081 \mathrm{~d}$ & $11.14 \pm 0.105 d$ & $1.01 \pm 0.016 \mathrm{c}$ & - \\
\hline & OE & $47.36 \pm 0.042 \mathrm{~d}$ & $11.33 \pm 0.076 \mathrm{~d}$ & $11.50 \pm 0.112 \mathrm{ab}$ & $0.99 \pm 0.010 \mathrm{~d}$ & - \\
\hline & GE & $47.70 \pm 0.080 \mathrm{c}$ & $10.18 \pm 0.067 \mathrm{e}$ & $11.01 \pm 0.084 \mathrm{e}$ & $0.92 \pm 0.001 \mathrm{e}$ & - \\
\hline & CE & $47.71 \pm 0.084 c$ & $11.70 \pm 0.057 \mathrm{c}$ & $11.49 \pm 0.103 \mathrm{ab}$ & $1.02 \pm 0.007 \mathrm{c}$ & - \\
\hline & TC & $48.49 \pm 0.068 \mathrm{a}$ & $12.07 \pm 0.138 \mathrm{a}$ & $11.43 \pm 0.073 b$ & $1.06 \pm 0.008 \mathrm{a}$ & - \\
\hline & BHA/BHT & $47.40 \pm 0.112 \mathrm{~d}$ & $11.90 \pm 0.079 \mathrm{~b}$ & $11.29 \pm 0.024 \mathrm{c}$ & $1.05 \pm 0.009 \mathrm{a}$ & - \\
\hline \multirow[t]{8}{*}{6} & CON & $47.27 \pm 0.067 \mathrm{f}$ & $8.24 \pm 0.076 \mathrm{f}$ & $10.05 \pm 0.065 \mathrm{e}$ & $0.82 \pm 0.009 \mathrm{e}$ & - \\
\hline & RE & $48.81 \pm 0.143 \mathrm{ab}$ & $11.03 \pm 0.072 \mathrm{a}$ & $11.08 \pm 0.098 \mathrm{a}$ & $1.00 \pm 0.003 \mathrm{ab}$ & - \\
\hline & SE & $48.64 \pm 0.084 c$ & $10.76 \pm 0.050 \mathrm{c}$ & $10.69 \pm 0.089 \mathrm{c}$ & $1.01 \pm 0.011 \mathrm{a}$ & - \\
\hline & OE & $48.67 \pm 0.059 c$ & $10.64 \pm 0.131 d$ & $10.89 \pm 0.084 b$ & $0.98 \pm 0.017 \mathrm{c}$ & - \\
\hline & GE & $48.05 \pm 0.139 \mathrm{~d}$ & $9.06 \pm 0.065 \mathrm{e}$ & $10.42 \pm 0.124 \mathrm{~d}$ & $0.87 \pm 0.008 \mathrm{~d}$ & - \\
\hline & CE & $48.75 \pm 0.047 b c$ & $10.89 \pm 0.054 b$ & $11.01 \pm 0.066 \mathrm{a}$ & $0.99 \pm 0.010 \mathrm{bc}$ & - \\
\hline & TC & $48.92 \pm 0.057 \mathrm{a}$ & $10.98 \pm 0.104 \mathrm{ab}$ & $10.99 \pm 0.074 \mathrm{ab}$ & $1.00 \pm 0.012 \mathrm{ab}$ & - \\
\hline & BHA/BHT & $47.85 \pm 0.103 \mathrm{e}$ & $10.70 \pm 0.077 \mathrm{~cd}$ & $10.76 \pm 0.109 \mathrm{c}$ & $0.99 \pm 0.009 \mathrm{ab}$ & - \\
\hline \multirow[t]{8}{*}{9} & CON & $47.90 \pm 0.086 \mathrm{~h}$ & $7.62 \pm 0.086 \mathrm{~g}$ & $9.44 \pm 0.052 \mathrm{~g}$ & $0.81 \pm 0.012 \mathrm{e}$ & - \\
\hline & RE & $49.83 \pm 0.062 b$ & $10.34 \pm 0.128 \mathrm{~b}$ & $10.79 \pm 0.146 \mathrm{ab}$ & $0.96 \pm 0.010 \mathrm{~b}$ & - \\
\hline & SE & $49.18 \pm 0.116 \mathrm{~d}$ & $9.36 \pm 0.042 \mathrm{e}$ & $10.30 \pm 0.084 \mathrm{e}$ & $0.91 \pm 0.010 \mathrm{~d}$ & - \\
\hline & OE & $49.59 \pm 0.067 \mathrm{c}$ & $9.49 \pm 0.153 \mathrm{~d}$ & $10.51 \pm 0.119 \mathrm{~d}$ & $0.90 \pm 0.015 d$ & - \\
\hline & GE & $48.69 \pm 0.091 \mathrm{~g}$ & $8.19 \pm 0.029 f$ & $10.09 \pm 0.150 \mathrm{f}$ & $0.81 \pm 0.014 \mathrm{e}$ & - \\
\hline & $\mathbf{C E}$ & $48.90 \pm 0.080 \mathrm{e}$ & $10.52 \pm 0.081 \mathrm{a}$ & $10.68 \pm 0.088 \mathrm{bc}$ & $0.98 \pm 0.012 \mathrm{a}$ & - \\
\hline & TC & $49.96 \pm 0.035 \mathrm{a}$ & $10.42 \pm 0.101 \mathrm{ab}$ & $10.86 \pm 0.068 \mathrm{a}$ & $0.96 \pm 0.011 b$ & - \\
\hline & ВНА/ВHT & $48.79 \pm 0.068 \mathrm{f}$ & $9.89 \pm 0.087 \mathrm{c}$ & $10.62 \pm 0.125 \mathrm{~cd}$ & $0.93 \pm 0.007 \mathrm{c}$ & - \\
\hline \multirow[t]{8}{*}{12} & CON & $48.47 \pm 0.096 \mathrm{e}$ & $7.14 \pm 0.079 \mathrm{e}$ & $9.52 \pm 0.153 \mathrm{f}$ & $0.75 \pm 0.012 \mathrm{e}$ & - \\
\hline & RE & $50.95 \pm 0.162 \mathrm{a}$ & $9.96 \pm 0.132 \mathrm{a}$ & $10.36 \pm 0.051 b$ & $0.96 \pm 0.013 b c$ & - \\
\hline & SE & $49.93 \pm 0.069 b$ & $8.95 \pm 0.058 \mathrm{c}$ & $9.98 \pm 0.120 \mathrm{de}$ & $0.90 \pm 0.005 \mathrm{~d}$ & - \\
\hline & OE & $50.04 \pm 0.102 b$ & $8.90 \pm 0.084 c$ & $10.06 \pm 0.122 \mathrm{~d}$ & $0.88 \pm 0.017 \mathrm{~d}$ & - \\
\hline & GE & $49.32 \pm 0.068 \mathrm{~d}$ & $7.36 \pm 0.067 \mathrm{~d}$ & $9.89 \pm 0.130 \mathrm{e}$ & $0.74 \pm 0.011 \mathrm{e}$ & - \\
\hline & CE & $49.69 \pm 0.125 \mathrm{c}$ & $10.02 \pm 0.073 \mathrm{a}$ & $10.21 \pm 0.072 \mathrm{c}$ & $0.98 \pm 0.008 \mathrm{a}$ & - \\
\hline & TC & $51.07 \pm 0.048 \mathrm{a}$ & $10.05 \pm 0.076 \mathrm{a}$ & $10.51 \pm 0.084 \mathrm{a}$ & $0.96 \pm 0.014 \mathrm{c}$ & - \\
\hline & ВНА/ВНТ & $49.22 \pm 0.085 \mathrm{~d}$ & $9.80 \pm 0.036 \mathrm{~b}$ & $10.09 \pm 0.089 \mathrm{~cd}$ & $0.97 \pm 0.008 \mathrm{ab}$ & - \\
\hline \multirow[t]{8}{*}{15} & CON & $48.37 \pm 0.112 \mathrm{e}$ & $6.81 \pm 0.084 \mathrm{~d}$ & $9.64 \pm 0.137 \mathrm{c}$ & $0.71 \pm 0.012 \mathrm{c}$ & $6.68 \pm 0.124 \mathrm{~b}$ \\
\hline & RE & $50.80 \pm 0.079 a$ & $9.53 \pm 0.147 \mathrm{a}$ & $10.09 \pm 0.076 \mathrm{ab}$ & $0.94 \pm 0.012 \mathrm{a}$ & $6.08 \pm 0.185 c$ \\
\hline & SE & $50.42 \pm 0.155 b$ & $8.37 \pm 0.086 c$ & $9.71 \pm 0.103 \mathrm{c}$ & $0.86 \pm 0.014 b$ & $6.58 \pm 0.160 \mathrm{~b}$ \\
\hline & OE & $49.94 \pm 0.165 c$ & $8.44 \pm 0.044 c$ & $9.73 \pm 0.159 \mathrm{c}$ & $0.87 \pm 0.011 \mathrm{~b}$ & $6.20 \pm 0.151 \mathrm{c}$ \\
\hline & GE & $49.52 \pm 0.149 \mathrm{~d}$ & $6.92 \pm 0.128 \mathrm{~d}$ & $9.65 \pm 0.096 \mathrm{c}$ & $0.72 \pm 0.017 \mathrm{c}$ & $7.10 \pm 0.206 a$ \\
\hline & CE & $49.92 \pm 0.107 \mathrm{c}$ & $9.30 \pm 0.101 b$ & $10.03 \pm 0.056 b$ & $0.93 \pm 0.010 \mathrm{a}$ & $5.54 \pm 0.129 \mathrm{~d}$ \\
\hline & TC & $50.93 \pm 0.066 \mathrm{a}$ & $9.56 \pm 0.069 \mathrm{a}$ & $10.21 \pm 0.065 \mathrm{a}$ & $0.94 \pm 0.007 \mathrm{a}$ & $6.13 \pm 0.093 \mathrm{c}$ \\
\hline & BHA/BHT & $49.65 \pm 0.098 d$ & $9.27 \pm 0.183 b$ & $9.98 \pm 0.071 b$ & $0.93 \pm 0.020 \mathrm{a}$ & $5.38 \pm 0.155 \mathrm{~d}$ \\
\hline
\end{tabular}

CON: control (without antioxidant); RE: $0.2 \mathrm{~g}$ rosemary extract $/ \mathrm{kg}$ meat; SE: $0.2 \mathrm{~g}$ sage extract $/ \mathrm{kg}$ meat; OE: $0.2 \mathrm{~g}$ oregano extract $/ \mathrm{kg}$ meat; GE: $0.2 \mathrm{~g}$ ginger extract $/ \mathrm{kg}$ meat; CE: $0.2 \mathrm{~g}$ clove extract $/ \mathrm{kg}$ meat; TC: $0.2 \mathrm{~g}$ tea catechins $/ \mathrm{kg}$ meat; BHA $/ \mathrm{BHT}: 0.2 \mathrm{~g} \mathrm{BHA} / \mathrm{BHT}(1: 1) / \mathrm{kg}$ meat. $L^{*}=$ lightness; $a^{*}=$ redness; $b^{*}=$ yellowness

Means in the same column for the same storage day with a different letter $(\mathrm{a}-\mathrm{g})$ differ significantly $(\mathrm{p}<0.05)$ 
Table (5): Effect of natural and synthetic antioxidants on sensory attributes of beef burgers during storage at $4 \pm 1^{\circ} \mathrm{C}$

\begin{tabular}{|c|c|c|c|c|c|c|}
\hline $\begin{array}{l}\text { Storage time } \\
\text { (days) }\end{array}$ & Treatment & Colour & Texture & Odour & Taste & $\begin{array}{l}\text { Overall } \\
\text { acceptability }\end{array}$ \\
\hline \multirow[t]{8}{*}{0} & $\mathrm{CON}$ & $8.55 \pm 0.284 a b$ & $8.10 \pm 0.516 a$ & $8.25 \pm 0.264 a$ & $8.80 \pm 0.350 \mathrm{a}$ & $7.95 \pm 0.798 \mathrm{a}$ \\
\hline & RE & $8.60 \pm 0.211 \mathrm{ab}$ & $7.80 \pm 1.006 \mathrm{a}$ & $8.30 \pm 0.258 \mathrm{a}$ & $8.70 \pm 0.258 \mathrm{ab}$ & $8.10 \pm 0.615 \mathrm{a}$ \\
\hline & SE & $8.65 \pm 0.338 \mathrm{ab}$ & $7.75 \pm 0.979 a$ & $8.05 \pm 0.643 a$ & $8.70 \pm 0.422 \mathrm{ab}$ & $8.00 \pm 0.624 a$ \\
\hline & OE & $8.45 \pm 0.284 b$ & $7.99 \pm 0.410 \mathrm{a}$ & $8.10 \pm 0.460 \mathrm{a}$ & $8.85 \pm 0.242 \mathrm{a}$ & $7.80 \pm 0.823 \mathrm{a}$ \\
\hline & GE & $8.70 \pm 0.422 \mathrm{ab}$ & $8.15 \pm 0.580 \mathrm{a}$ & $7.95 \pm 0.438 \mathrm{a}$ & $8.50 \pm 0.408 \mathrm{~b}$ & $7.73 \pm 0.901 \mathrm{a}$ \\
\hline & CE & $8.75 \pm 0.354 a$ & $8.25 \pm 0.540 \mathrm{a}$ & $7.96 \pm 0.427 \mathrm{a}$ & $8.60 \pm 0.394 a b$ & $8.13 \pm 0.637 a$ \\
\hline & TC & $8.60 \pm 0.211 \mathrm{ab}$ & $8.05 \pm 0.599 a$ & $8.20 \pm 0.350 \mathrm{a}$ & $8.65 \pm 0.242 \mathrm{ab}$ & $8.33 \pm 0.501 \mathrm{a}$ \\
\hline & BHA/BHT & $8.80 \pm 0.258 \mathrm{a}$ & $7.98 \pm 0.650 \mathrm{a}$ & $8.25 \pm 0.354 \mathrm{a}$ & $8.50 \pm 0.333 b$ & $8.23 \pm 0.448 \mathrm{a}$ \\
\hline \multirow[t]{8}{*}{3} & CON & $7.70 \pm 0.350 \mathrm{~d}$ & $7.85 \pm 0.412 \mathrm{a}$ & $7.45 \pm 0.369 \mathrm{~d}$ & $7.30 \pm 0.715 c$ & $6.40 \pm 0.699 b$ \\
\hline & RE & $8.30 \pm 0.350 \mathrm{abc}$ & $7.50 \pm 0.882 \mathrm{a}$ & $8.35 \pm 0.338 \mathrm{a}$ & $8.15 \pm 0.530 \mathrm{ab}$ & $7.60 \pm 0.966 \mathrm{a}$ \\
\hline & SE & $8.60 \pm 0.394 \mathrm{a}$ & $7.90 \pm 0.516 \mathrm{a}$ & $8.05 \pm 0.550 \mathrm{abc}$ & $7.95 \pm 0.685 \mathrm{ab}$ & $7.40 \pm 0.775 \mathrm{a}$ \\
\hline & OE & $8.20 \pm 0.789 \mathrm{abc}$ & $7.65 \pm 0.747 \mathrm{a}$ & $7.90 \pm 0.394 \mathrm{bc}$ & $7.90 \pm 0.738 \mathrm{ab}$ & $7.40 \pm 0.843 \mathrm{a}$ \\
\hline & GE & $7.85 \pm 0.580 \mathrm{~cd}$ & $7.90 \pm 0.658 \mathrm{a}$ & $7.80 \pm 0.350 \mathrm{c}$ & $7.60 \pm 0.709 b c$ & $7.30 \pm 0.856 \mathrm{a}$ \\
\hline & CE & $8.30 \pm 0.350 \mathrm{abc}$ & $8.00 \pm 0.624 a$ & $7.98 \pm 0.381 b c$ & $8.05 \pm 0.685 \mathrm{ab}$ & $7.62 \pm 0.977 \mathrm{a}$ \\
\hline & TC & $8.45 \pm 0.497 \mathrm{ab}$ & $8.05 \pm 0.550 \mathrm{a}$ & $8.15 \pm 0.242 \mathrm{ab}$ & $8.20 \pm 0.483 a$ & $7.55 \pm 0.956 a$ \\
\hline & BHA/BHT & $8.10 \pm 0.394 \mathrm{bcd}$ & $7.80 \pm 0.675 \mathrm{a}$ & $8.05 \pm 0.438 \mathrm{abc}$ & $7.95 \pm 0.497 \mathrm{ab}$ & $7.50 \pm 0.913 \mathrm{a}$ \\
\hline \multirow[t]{8}{*}{6} & CON & $7.15 \pm 0.669 b$ & $7.90 \pm 0.615 a$ & $6.00 \pm 0.333 \mathrm{~d}$ & $6.93 \pm 1.000 \mathrm{~b}$ & $5.80 \pm 0.747 \mathrm{~b}$ \\
\hline & RE & $8.05 \pm 0.497 \mathrm{a}$ & $7.65 \pm 0.626 \mathrm{a}$ & $7.05 \pm 0.550 \mathrm{a}$ & $7.73 \pm 0.506 \mathrm{ab}$ & $7.05 \pm 0.985 \mathrm{a}$ \\
\hline & SE & $8.03 \pm 0.478 \mathrm{a}$ & $7.75 \pm 0.589 a$ & $6.80 \pm 0.483 \mathrm{ab}$ & $7.40 \pm 0.568 \mathrm{ab}$ & $6.90 \pm 0.937 \mathrm{a}$ \\
\hline & OE & $7.80 \pm 0.587 \mathrm{a}$ & $7.50 \pm 0.882 \mathrm{a}$ & $6.55 \pm 0.369 b c$ & $7.50 \pm 1.054 \mathrm{ab}$ & $6.90 \pm 1.174 \mathrm{a}$ \\
\hline & GE & $7.70 \pm 0.538 \mathrm{ab}$ & $7.85 \pm 0.580 \mathrm{a}$ & $6.40 \pm 0.460 \mathrm{c}$ & $7.05 \pm 0.896 \mathrm{ab}$ & $6.70 \pm 1.135 \mathrm{ab}$ \\
\hline & CE & $7.95 \pm 0.497 \mathrm{a}$ & $7.80 \pm 0.675 \mathrm{a}$ & $6.90 \pm 0.394 \mathrm{ab}$ & $7.80 \pm 0.856 \mathrm{a}$ & $7.04 \pm 0.980 \mathrm{a}$ \\
\hline & TC & $8.03 \pm 0.786 a$ & $7.90 \pm 0.843 a$ & $7.00 \pm 0.408 \mathrm{a}$ & $7.65 \pm 1.001 \mathrm{ab}$ & $7.15 \pm 0.973 a$ \\
\hline & BHA/BHT & $7.80 \pm 0.919 \mathrm{a}$ & $7.80 \pm 0.978 \mathrm{a}$ & $6.80 \pm 0.483 \mathrm{ab}$ & $7.50 \pm 1.155 \mathrm{ab}$ & $7.00 \pm 0.624 a$ \\
\hline \multirow[t]{8}{*}{9} & CON & $6.25 \pm 0.589 \mathrm{~d}$ & $7.20 \pm 0.789 a$ & $5.30 \pm 0.633 \mathrm{~d}$ & $6.05 \pm 0.956 b$ & $5.75 \pm 0.755 b$ \\
\hline & RE & $7.70 \pm 0.350 \mathrm{a}$ & $7.35 \pm 0.626 \mathrm{a}$ & $6.90 \pm 0.658 \mathrm{a}$ & $7.30 \pm 0.888 \mathrm{a}$ & $6.70 \pm 0.978 \mathrm{a}$ \\
\hline & $\mathbf{S E}$ & $7.75 \pm 0.486 \mathrm{a}$ & $7.50 \pm 0.577 \mathrm{a}$ & $6.10 \pm 0.516 b c$ & $6.95 \pm 1.066 \mathrm{a}$ & $6.40 \pm 1.287 \mathrm{ab}$ \\
\hline & OE & $7.10 \pm 0.615 b c$ & $7.30 \pm 0.823 \mathrm{a}$ & $6.25 \pm 0.354 b c$ & $6.90 \pm 1.075 \mathrm{ab}$ & $6.55 \pm 1.166 \mathrm{ab}$ \\
\hline & GE & $6.78 \pm 0.721 \mathrm{~cd}$ & $7.45 \pm 0.864 a$ & $6.00 \pm 0.408 \mathrm{c}$ & $6.50 \pm 0.667 \mathrm{ab}$ & $5.90 \pm 0.843 \mathrm{ab}$ \\
\hline & CE & $7.50 \pm 0.527 \mathrm{ab}$ & $7.13 \pm 0.616 \mathrm{a}$ & $6.75 \pm 0.635 a$ & $7.25 \pm 0.890$ & $6.63 \pm 1.029 \mathrm{ab}$ \\
\hline & TC & $7.60 \pm 0.699 \mathrm{ab}$ & $7.40 \pm 0.843 a$ & $6.95 \pm 0.497 \mathrm{a}$ & $7.35 \pm 1.029 a$ & $6.78 \pm 1.088 \mathrm{a}$ \\
\hline & ВНА/ВНT & $7.50 \pm 0.707 \mathrm{ab}$ & $7.45 \pm 0.956 \mathrm{a}$ & $6.50 \pm 0.408 \mathrm{ab}$ & $7.25 \pm 1.184 \mathrm{a}$ & $6.60 \pm 1.049 \mathrm{ab}$ \\
\hline \multirow[t]{8}{*}{12} & CON & $6.00 \pm 0.667 \mathrm{~b}$ & $7.00 \pm 1.054 \mathrm{a}$ & $4.10 \pm 0.460 \mathrm{~d}$ & $5.13 \pm 0.907 \mathrm{c}$ & $4.75 \pm 0.950 \mathrm{c}$ \\
\hline & $\mathbf{R E}$ & $7.20 \pm 0.538 \mathrm{a}$ & $6.95 \pm 0.643 a$ & $6.45 \pm 0.599 \mathrm{a}$ & $6.95 \pm 0.927 \mathrm{a}$ & $6.25 \pm 0.890 \mathrm{a}$ \\
\hline & SE & $7.13 \pm 0.615 a$ & $6.90 \pm 0.810 \mathrm{a}$ & $5.75 \pm 0.540 b$ & $6.70 \pm 1.160 \mathrm{ab}$ & $5.90 \pm 1.022 \mathrm{ab}$ \\
\hline & OE & $7.03 \pm 0.606 \mathrm{a}$ & $6.80 \pm 0.753 \mathrm{a}$ & $5.65 \pm 0.412 b$ & $6.63 \pm 0.680 \mathrm{ab}$ & $5.80 \pm 0.919 \mathrm{ab}$ \\
\hline & GE & $6.20 \pm 0.789 b$ & $6.75 \pm 0.589 a$ & $5.10 \pm 0.394 c$ & $5.95 \pm 0.685 b c$ & $5.20 \pm 0.823 b c$ \\
\hline & CE & $7.05 \pm 0.762 \mathrm{a}$ & $6.90 \pm 0.810 \mathrm{a}$ & $6.30 \pm 0.538 \mathrm{a}$ & $6.88 \pm 0.775 \mathrm{a}$ & $6.30 \pm 0.978 \mathrm{a}$ \\
\hline & TC & $7.10 \pm 0.658 \mathrm{a}$ & $7.02 \pm 0.297 \mathrm{a}$ & $6.60 \pm 0.316 \mathrm{a}$ & $7.00 \pm 0.943 \mathrm{a}$ & $6.40 \pm 0.876 \mathrm{a}$ \\
\hline & BHA/BHT & $7.00 \pm 0.817 \mathrm{a}$ & $7.00 \pm 1.202 \mathrm{a}$ & $6.40 \pm 0.738 \mathrm{a}$ & $6.80 \pm 1.358 \mathrm{ab}$ & $6.25 \pm 0.825 \mathrm{a}$ \\
\hline \multirow[t]{8}{*}{15} & CON & $5.20 \pm 0.633 c$ & $6.55 \pm 1.117 \mathrm{a}$ & $3.75 \pm 0.717 \mathrm{e}$ & $4.80 \pm 1.033 \mathrm{c}$ & $3.80 \pm 0.633 c$ \\
\hline & RE & $7.05 \pm 0.438 \mathrm{a}$ & $6.65 \pm 1.029 \mathrm{a}$ & $5.95 \pm 0.643 \mathrm{ab}$ & $6.65 \pm 1.180 \mathrm{a}$ & $6.10 \pm 1.287 \mathrm{a}$ \\
\hline & SE & $6.95 \pm 0.550 \mathrm{a}$ & $6.50 \pm 0.850 \mathrm{a}$ & $5.40 \pm 0.394 c$ & $6.30 \pm 1.059 \mathrm{a}$ & $5.85 \pm 1.668 \mathrm{ab}$ \\
\hline & OE & $6.90 \pm 0.568 \mathrm{a}$ & $6.40 \pm 1.075 \mathrm{a}$ & $5.45 \pm 0.369 b c$ & $6.20 \pm 1.135 \mathrm{ab}$ & $5.75 \pm 1.275 \mathrm{ab}$ \\
\hline & GE & $6.00 \pm 0.408 b$ & $6.45 \pm 0.762 \mathrm{a}$ & $4.30 \pm 0.587 \mathrm{~d}$ & $5.30 \pm 1.006 \mathrm{bc}$ & $4.90 \pm 0.516 b$ \\
\hline & CE & $6.80 \pm 0.856 \mathrm{a}$ & $6.65 \pm 0.818 \mathrm{a}$ & $5.90 \pm 0.394 \mathrm{abc}$ & $6.60 \pm 1.174 \mathrm{a}$ & $5.95 \pm 1.383 \mathrm{ab}$ \\
\hline & TC & $6.95 \pm 0.685 a$ & $6.70 \pm 0.949 \mathrm{a}$ & $6.10 \pm 0.810 \mathrm{a}$ & $6.65 \pm 0.973 a$ & $6.15 \pm 1.107 a$ \\
\hline & ВHA/BHT & $6.80 \pm 1.085 \mathrm{a}$ & $6.55 \pm 1.166 \mathrm{a}$ & $5.85 \pm 0.669 a b c$ & $6.50 \pm 1.247 \mathrm{a}$ & $5.90 \pm 0.810 \mathrm{ab}$ \\
\hline
\end{tabular}

CON: control (without antioxidant); RE: $0.2 \mathrm{~g}$ rosemary extract $/ \mathrm{kg}$ meat; SE: $0.2 \mathrm{~g}$ sage extract $/ \mathrm{kg}$ meat; OE: $0.2 \mathrm{~g}$ oregano extract $/ \mathrm{kg}$ meat; GE: $0.2 \mathrm{~g}$ ginger extract $/ \mathrm{kg}$ meat; CE: $0.2 \mathrm{~g}$ clove extract $/ \mathrm{kg}$ meat; TC: $0.2 \mathrm{~g}$ tea catechins $/ \mathrm{kg}$ meat; BHA $/$ BHT: $0.2 \mathrm{~g}$ BHA $/ \mathrm{BHT}(1: 1) / \mathrm{kg}$ meat.

Means in the same column for the same storage day with a different letter $(\mathrm{a}-\mathrm{g})$ differ significantly $(\mathrm{p}<0.05)$

higher flavour scores than those of other formulas during storage. Tang et al. (2006) reported that addition of TC at a level of $200 \mathrm{mg} / \mathrm{kg}$ meat improved colour stability in beef patties and prolonged the colour shelf life by 2 days, the colour stabilizing effect of TC in beef may be due delaying oxidation of oxymyoglobin in muscle via inhibition of lipid oxidation. Furthermore, a high positive correlation between TBARS values and trained panel scores for cooked beef was noted when stored at $4{ }^{\circ} \mathrm{C}$ for $1-3$ days (Younathan et al., 1980). Sánchez-Escalante et al. (2001) also reported that the presence of rosemary, both alone and with ascorbic acid, extended the fresh meat colour and odour storage time. Sebrank et al., (2005) mentioned that frozen sausage treated with $2500 \mathrm{ppm}$ rosemary extract was significantly less brown than sausage treated with $\mathrm{BHA} / \mathrm{BHT}$ during the entire 16-week testing period.

\section{CONCLUSIONS}

From the obtained results, it can be concluded that the use of natural and synthetic antioxidants can reduce lipid oxidation, enhance colour stability and improve the sensory characteristics of beef burgers. Thus, addition 
of natural antioxidants is one of the ways to extend the durability of meat and meat products. The TC and RE provided the best antioxidant protection against beef burgers deterioration during 15 days of storage. Moreover, TC and RE are superior to BHA/BHT in inhibiting the lipid oxidation and improving the colour and sensory attributes of beef burgers during refrigerated storage. The $\mathrm{CE}, \mathrm{BHA} / \mathrm{BHT}, \mathrm{SE}$ and $\mathrm{OE}$ extracts proved to be effective antioxidants in beef burgers, while GE showed a small antioxidant effect. Because of the well-known health benefits of these highly effective extracts of natural antioxidant, their application in the meat industry may be very valuable and desirable.

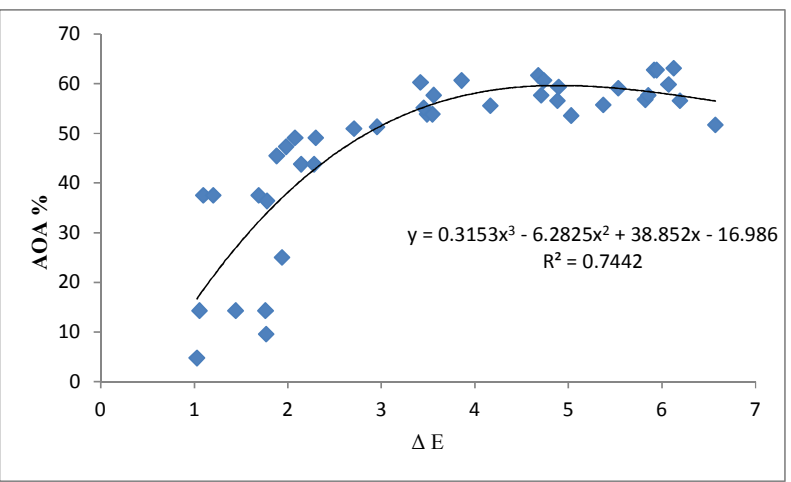

Figure 1. Correlation between antioxidant activity $(\mathrm{AOA} \%)$ and $\mathrm{A}$ numerical total colour difference $(\Delta \mathrm{E})$ in beef burgers treated with natural and synthetic antioxidants and stored at $4 \pm 1{ }^{\circ} \mathrm{C}$ for 15 days.

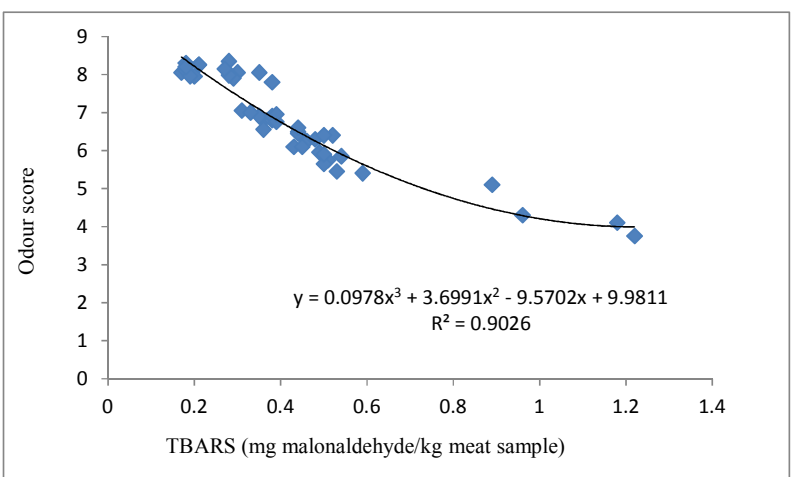

Figure 2. Correlation between lipid oxidation (TBARS values) and odour (sensorial scores) in beef burgers treated with natural and synthetic antioxidants and stored at $4 \pm 1{ }^{\circ} \mathrm{C}$ for 15 days.

\section{REFERENCES}

A.O.A.C. (2000). Official methods of analysis of the Association of Official Analytical Chemists. Published by the A.O.A.C. International 18th Ed. Washington, D.C., USA.

Aruoma, O. I., Spencer, J. P. E., Rossi, R., Aeschbach, R., Khan, A., Mahmood, N., Munoz, A., Murcia, A., Butler, J. and Halliwell, B. (1996). An evaluation of the antioxidant and antiviral action of extracts of rosemary and provencal herbs. Food Chem. Toxicol., 34, 449-456.
Asghar, A., Gray, J. I., Buckley, D. J., Pearson, A. M. and Booren, A. M. (1988). Perspectives on warmedover flavour. Food Technol., 42, 102-108.

Boulianne, M. and King, A. J. (1998). Meat color and biochemical characteristics of unaccepted darkcolored broiler chicken carcasses. J. Food Sci., 63,759-762.

Brown, J. E., Khodr, H., Hider, R.C., Rice-Evans, C. A. (1998). Structural dependence of flavonoid interactions with $\mathrm{Cu}^{2+}$ ions: implications for their antioxidant properties. J Biochem., 330, 1173-1178.

Chen X, Jo C, Lee JI, Ahn DU. 1999. Lipid oxidation, volatiles and color changes of irradiated pork patties as affected by antioxidants. Journal of Food Science 64, 16-19.

Chen, H. H., Chiu, E. M., \& Huang, J. R. (1997). Color and gel-forming properties of horse mackerel (Trachurus japonucus) as related to washing conditions. Journal of Food Science, 62, 985-991.

Djenane, D., Montañés, L., Roncalés, P. (2005). Nuevas perspectivas para la conservación natural de la carne. Eurocarne, 133, 153-180

Dorman, H. J. D., Peltoketo, A., Hiltunen, R. and Tikkanen, M. J. (2003). Characterization of the antioxidant properties of de-odourised aqueous extracts from selected Lamiaceae herbs. Food Chem., 83, 255-262.

Estévez, M., Ventanas, S. and Cava, R. (2006). Effect of natural and synthetic antioxidants on protein oxidation and colour and texture changes in refrigerated stored porcine liver pâté. Meat Sci., 74, 396-403.

Fang, X. and Wada, S. (1993). Enhancing the antioxidant effect of $\alpha$-tocopherol with rosemary in inhibiting catalyzed oxidation caused by $\mathrm{Fe}^{2+}$ and hemoprotein. Food Res. Int., 26, 405-411.

Fasseas, M. K., Mountzouris, K. C., Tarantilis, P. A., Polissiou, M. and Zervas, G. (2008). Antioxidant activity in meat treated with oregano and sage essential oils. Food Chem., 106, 1188-1194.

Faustman, C., Yin, M. C. and Nadeau, D. B. (1992). Color stability, lipid stability, and nutrient composition of red and white veal. J. Food Sci., 57, 302-304.

Fenaille, F., Visani, P., Fumeaux, R., Milo, C. and Guy, P. (2003). Comparison of mass spectrometry-based electronic nose and solid phase micro extraction gas chromatography mass spectrometry technique to assess infant formula oxidation. J. Agr. Food Chem., 51, 2790-2796.

Fleming, B. K., Froning, G. W. and Yang, T. S. (1991). Heme pigment levels in chicken broilers chilled in ice slush and air. Poultry Sci., 57, 630-633.

Formanek, Z., Kerry, J. P., Higgins, F. M., Buckley, D. J., Morrissey, P. A., Farkas, J. (2001). Addition of synthetic and natural antioxidants to alphatocopheryl acetate supplemented beef patties: Effects of antioxidants and packaging on lipid oxidation. Meat Sci., 58, 337-341.

García, M. L., Calvo, M. M. and Selgas, M. D. (2009). Beef hamburgers enriched in lycopene using dry tomato peel as an ingredient. Meat Sci., 83, 45-49. 
Gill, C. O. (1983). Meat spoilage and evalution of the potential storage life of fresh meat. J. Food Prot., 46, 444-452.

Goodridge, C., Beaudry, R., Pestka, J. and Smith, D. (2003). Solid phase microextraction- gas chromatography for quantifying headspace hexanal above freeze-dried chicken myofibrils. J. Agr. Food Chem., 51, 4185-4190.

Ibrahim, H. M., Abou-arab, A. A. and Abu Salam, F. M. (2010). Addition of some natural plant extracts and their effects on lamb patties quality. J. Food Technol., 8, 134-142.

Ibrahim, H. M., Abou-Arab, A. A. and Abu Salem, F. M. (2011). Antioxidant and antimicrobial effects of some natural plant extracts added to lamb patties during storage, Grasas Y Aceites, 62, 139-148.

Insani, E. M., Eyherabide, A., Grigioni, G., Sancho, A. M., Pensel, N. A. and Descalzo, A. M. (2008). Oxidative stability and its relationship with natural antioxidants during refrigerated retail display of beef produced in Argentina. Meat Sci., 79, 444-452.

Jay, J. M. (1996). Antioxidants. In: (J. M. Jay, Ed.) Modern Food Microbiology (4 ${ }^{\text {th }}$ Ed.), CBS Publishers and Distributors, New Delhi, India, pp. 265-266.

Jenschke, B. E. (2004). Chemical, color, and sensory attributes of sorghum bran enhanced beef patties in a high oxygen environment [M.Sc. Thesis] Texas A\&M University, USA.

Kanatt, S. R., Chander, R. and Sharma, A. (2010). Antioxidant and antimicrobial activity of pomegranate peel extract improves the shelf life of chicken products. Int. J. Food Sci. Technol., 45, 216222.

Karakaya, M., Bayrak, E. and Ulusoy, K. (2011). Use of natural antioxidants in meat and meat Products. J. Food Sci. Eng., 1, 1-10.

Kolakowska, A. (2003). Lipid Oxidation in Food Systems. In: Chemical and Functional Properties of Food Lipids (Chapter 8). CRC Press LLC.

Kong, B., Zhang, H., and Xiong, Y. L. (2010). Antioxidant activity of spice extracts in a liposome system and in cooked pork patties and the possible mode of action. Meat Sci., 85, 772-778.

Lee, S., Joo, S. T., Alderton, A. L., Hill, D. W. and Faustman, C. (2003). Oxymyoglobin and lipid oxidation in yellowfin tuna (Thunnus albacares) loins. J. Food Sci., 68, 1664-1668.

Li, M. Y., Zhou, G. H., Xu, X. L., Li, C. B. and Zhu, W. Y. (2006). Changes of bacterial diversity and main flora in chilled pork during storage using PCRDGGE. Food Microbiol., 23, 607-611.

Lindberg Madsen, H. and Bertelsen, G. (1995). Spices as antioxidants. Trends Food Sci. Technol., 6, 271277.

Maher, M., O $\square$ Grady, M. N., Buckley, D. J., Troy, D., Moloney, A. P. and Kerry, J. P. (2002). Effect of dietary supplementation and direct addition of tea catechins and rosemary on the oxidative stability of beef. In Proceedings of the $48^{\text {th }}$ International Congress of Meat Science and Technology, 25-30 August 2002, Rome, Italy, pp. 500-501.
Martinez-Tome, M., Jimenez, A. M., Ruggieri, S., Frega, N., Strabbioli, R. and Murcia, M. A. (2001). Antioxidant properties of Mediterranean spices compared with common food additives. J. Food Prot., 64, 1412-1419.

McCarthy, T. L., Kerry, J. P., Kerry, J. F., Lynch, P. B. and Buckley, D. J. (2001). Evaluation of the antioxidant potential of natural food/plant extracts as compared with synthetic antioxidants and vitamin $\mathrm{E}$ in raw and cooked pork patties. Meat Sci., 57, 45-52.

McMillin, K.W. (1996). Initiation of oxidative processes in muscle foods. Reciprocal Meat Conferences Proceedings, 49, 53-64.

Mitsumoto, M., O $\square$ Grady, M. N., Kerry, J. P. and Buckley, D. J. (2005). Addition of tea catechins and vitamin $\mathrm{C}$ on sensory evaluation, colour and lipid stability during chilled storage in cooked or raw beef and chicken patties. Meat Sci., 69, 773-779.

Mohamed, H. M. H. and Mansour, H. A. (2012). Incorporating essential oils of marjoram and rosemary in the formulation of beef patties manufactured with mechanically deboned poultry meat to improve the lipid stability and sensory attributes. LWT- Food Sci. Technol., 45, 79-87.

Murphy, A., Kerry, J.P., Buckley, J. and Gray, R. (1998). The antioxidative properties of rosemary oleoresin and inhibition of off-flavors in precooked roast beef slices. J. Sci. Food Agric., 77, 235-243.

Naveena, B. M., Muthukumar, M., Sen, A. R., Babji, Y. and Murthy, T. R. K. (2006). Improvement of shelflife of buffalo meat using lactic acid, clove oil and vitamin $\mathrm{C}$ during retail display. Meat Sci., 74, 409-415.

Negi, P. S. and Jayaprakasha, G. K. (2003). Antioxidant and Antibacterial Activities of Punica granatum Peel Extracts. J. Food Sci., 68, 1473-1477.

Nissen, L. R., Byrne, D. V., Bertelsen, G. and Skibsted, L. H. (2004). The antioxidative activity of plant extracts in cooked pork patties as evaluated by descriptive sensory profiling and chemical analysis. Meat Sci., 68, 485-495.

Rajalakshmi, D. and Narasimhan, S. (1996). Food antioxidants: sources and methods of evaluation. In (D. L. Madhavi, S. S. Deshpande and D. K. Salunkhe, Eds.), Food Antioxidants, Marcel Dekker, NewYork, pp. 65-157.

Ripoll, G., Joy, M. and Muñoz, F. (2011). Use of dietary vitamin $\mathrm{E}$ and selenium (Se) to increase the shelf life of modified atmosphere packaged light lamb meat. Meat Sci., 87, 88-93.

Sacchetti, G., Di Mattia, C., Pittia, P. and Martino, G. (2008). Application of a radical scavenging activity test to measure the total antioxidant activity of poultry meat. Meat Sci., 80, 1081-1085.

Sánchez-Escalante, A., Djenane, D., Torrescano, G., Beltrán, J. A. and Roncalés, P. (2001). The effects of ascorbic acid, taurine, carnosine and rosemary powder on colour and lipid stability of beef patties packaged in modified atmosphere. Meat Sci., 58, 421-429

Sebranek, J. G., Sewalt, V. J. H., Robbins, K. L. and Houser, T. A. (2005). Comparison of a natural rosemary extract and $\mathrm{BHA} / \mathrm{BHT}$ for relative 
antioxidant effectiveness in pork sausage. Meat Sci., 69, 289-296.

Shahidi, F. and Pegg, R. B. (1998). Inhibition of oxidation of meat lipids with spices and their oleoresins. In Proceedings of the $44^{\text {th }}$ International Congress of Meat Science and Technology, Volume II, August 30-September 4, Barcelona, Spain, pp. 680-681

Shahidi, F., Pegg, R. B. and Saleemi, Z. O. (1995). Stabilization of meat lipids with ground spices. J. Food Lipids, 2, 145-153.

Shahidi, F., Rubin, L. J. and Wood, D. F. (1987). Control of lipid oxidation in cooked ground pork with antioxidants and dinitrosyl ferrohemochrome, J. Food Sci., 52, 564-566.

Shan, B., Cai, Y., Brooks, J. D. and Corke, H. (2009). Antibacterial and antioxidant effects of five spice and herb extracts as natural preservatives of raw pork. J. Sci. Food Agric., 89, 1879-1885.

Tang, S. Z., Ou, S. Y., Huang, X. S., Li, W., Kerry, J. P. and Buckley, D. J. (2006). Effects of added tea catechins on colour stability and lipid oxidation in minced beef patties held under aerobic and modified atmosphere packaging conditions. J. Food Eng., 77, 248-253.

Tang, S., Sheehan, D., Buckley, D. J., Morrissey, P. A. and Kerry, J. P. (2001). Anti-oxidant activity of added tea catechins on lipid oxidation of raw minced red meat, poultry and fish muscle. Int. J. Food Sci. Technol., 36, 685-692.

Tarladgis, B. G., Watts, B. M., Younathan, M. T. and Dugan, L. (1960). A distillation method for the quantitative determination of malonaldehyde in rancid foods. J. Am. Oil Chem. Soc., 37, 44-48.

Trefan, L., Bürger, L., Bloom-Hansen, J., Rooke, J. A., Salmi, B., Larzul, C., Terlouw, C. and DoeschlWilson, A. (2011). Meta-analysis of the effects of dietary vitamin E supplementation on $\alpha$-tocopherol concentration and lipid oxidation in pork. Meat Sci., $87,305-314$.
Trindade, R. A., Mancini-filho, S., Sabundjian, I. T., Nunes, T. C. F., Rogvschi, V. D. and Villavicencio, A. L. C. H. (2007). Changes on lipids profile in beef burgers prepared with rosemary extracts and submitted to e-beam processing. INAC, Santos, SP, Brazil.

Trout, G. R. (2003). Biochemistry of lipid and myoglobin oxidation in post-mortem muscle and meat products. In Proceedings of the $49^{\text {th }}$ International Congress of Meat Science and Technology; $2^{\text {nd }}$ Brazilian Congress of Meat Science and Technology, 31 August - 5 September, Campinas, Brazil, pp. 50-55.

Vaithiyanathan, S., Naveena, B. M., Muthukumar, M., Girish, P. S. and Kondaiah, N. (2011). Effect of dipping in pomegranate (Punica granatum) fruit juice phenolic solution on the shelf life of chicken meat under refrigerated storage $\left(4^{\circ} \mathrm{C}\right)$. Meat Sci., $88,409-414$.

Vega-Gálvez, A., Ah-Hen, K., Chacana, M., Vergara, J. and Martínez-Monzó, J. (2012). Effect of temperature and air velocity on drying kinetics, antioxidant capacity, total phenolic content, colour, texture and microstructure of apple (var. Granny Smith) slices. Food Chem., 132, 51-59.

Yogesh, K. and Ali, J. (2014). Antioxidant potential of thuja (Thuja occidentalis) cones and peach (Prunus persia) seeds in raw chicken ground meat during refrigerated $\left(4 \pm 1^{\circ} \mathrm{C}\right)$ storage. J Food Sci Technol., $51,1547-1553$.

Younathan, M. T., Marjan, Z. M. and Arshad, F. B. (1980). Oxidative rancidity in stored ground beef. J. Food Sci., 45, 274-275.

Zheng, W. and Wang, S. Y. (2001). Antioxidant activity and phenolic compounds in selected herbs. J. Agric. Food Chem., 49, 5165-5170.

Zhong, R. Z., Tan, C. Y., Han, X. F., Tang, S. X., Tan, Z. L. and Zeng, B. (2009). Effect of dietary tea catechins supplementation in goats on the quality of meat kept under refrigeration. Small Ruminant Res., $87,122-125$.

\section{التأثير المضاد للأكسدة لبعض المستخلصات التباتية بالمقارنة بال BHA/BHT على أكسدة الدهون}

$$
\begin{aligned}
& \text { وبعض خصسائص الجودة لبرجر اللحم البقري المخزن على \&ْم } \\
& \text { سبي محمد مختار - خالا محمد يوسف الزيف }
\end{aligned}
$$

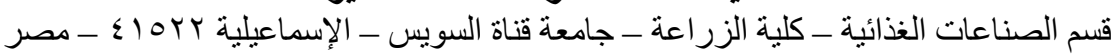

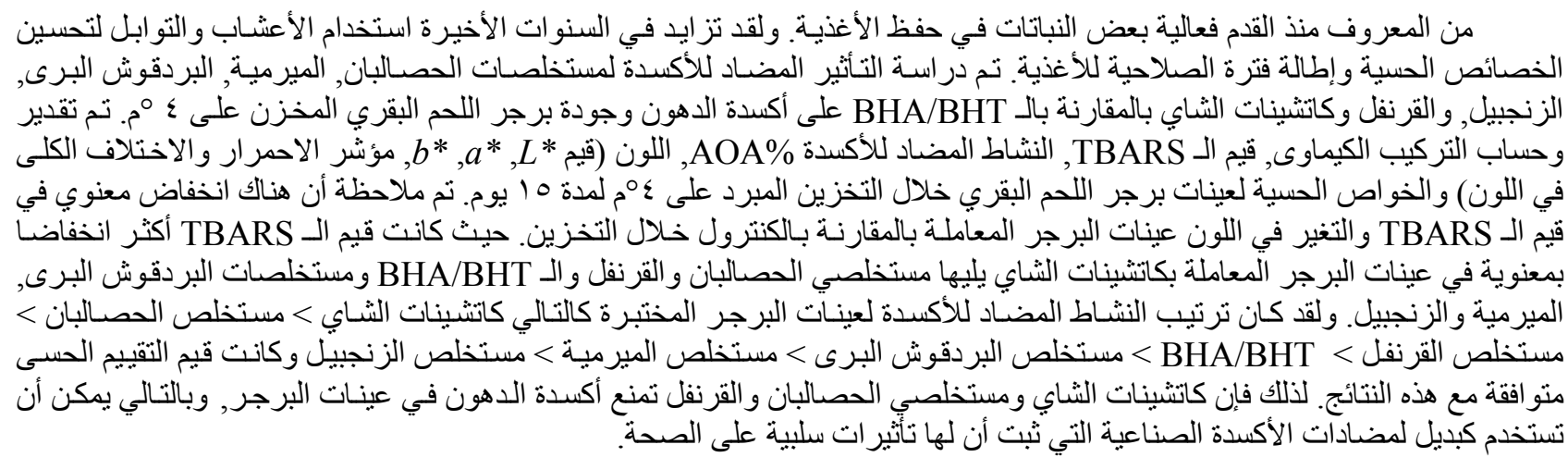

